\title{
On the Issue of the Theoretical Field of Architecture Revision in the Age of Computer Technologies*
}

\author{
Irina Dobritsyna \\ Scientific Research Institute of Theory and History of Architecture and Urban Planning \\ Branch of the Central Institute for Research and Design \\ Ministry of Construction and Housing and Communal Services of the Russian Federation \\ Moscow, Russia \\ E-mail: rinadobrits@mail.ru
}

\begin{abstract}
The characteristic extension of the subject of architecture and architectural theory in the conditions of computerization of the project process in the 21 st century is approved. Theoretical concepts of prominent Western theorists based on very different philosophical arguments are considered and compared. One of the main areas of research of architectural theory in the conditions of cybernetic expansion is the very consciousness of the architect.
\end{abstract}

Keywords-architectural theory; digital design; Christopher Hight; Neil Spiller; phenomenology; diagrams; modulus Corbusier; superreality; the phenomenon of "intermediate body"

\section{INTRODUCTION}

For several decades of the 20th century Russian architectural thought has cultivated avant-garde, classical and then modernist values of architecture. The alignment of the theoretical development, grounded in modern philosophy, began around the 1990s. Over the past 30 years, Russian architects have been included in the world problems of architecture rather as design practitioners. The scientific and philosophical development of the problems of architecture typical for the beginning of the 21 st century in Russia has not yet entered the intense rhythm of Western theorizing, heated by accelerated computerization.

The development of the Western architect's special sensitivity to the architectural computer program began in the middle of the 20th century. The picture of Western theoretical works on digital architecture in the 21 st century, on the threshold of the coming century of cybernetics is very unstable. Today, it is only clear that architecture as a discipline is a super-complex organism; and the creation of an architectural object does not allow computer arbitrariness. In other words, there is no ready-made fatal matrix or new «style» paradigm before architecture. Rather, there is the polyphony of theoretical approaches. There is no unity of a

*The Reported study was Funded by Science and Technology Development State Program of the Russian Federation for years 2013-2020 Program of Fundamental Research of State Academies of Science for years 2013-2020, within the Program of Fundamental Researches of Ministry of Construction, Housing and Utilities of the Russian Federation and Russian Academy of Architecture and Construction Sciences; the Research Project 1.4.7. conceptual field.

There is a number of the most significant and original figures, which had gained their reputation as pioneers in the scientific and philosophical exploration of the architecture of the 21 st century as a computer age phenomenon. This list will include pure theorists and experimental theorists concerned with propaedeutic experience - Antoine Picon, Mario Carpo, Christopher Hight, Neil Spiller, Patrik Schumacher.

The article compares the concepts of two theorists of architecture with seemingly opposite worldview - the American Christopher Hight, unwinding the line of invisible connection - with historically stable poetics - the poetics of physicality; and the Englishman Neil Spiller, who declares the inherent unity of virtual and actual (real) origin in the very nature of the man's world perception.

\section{Christopher Hight ARChitectural Principles IN THE AGE OF CYBERNETICS}

\section{A. The Outlines of the Theoretical Concept}

The theoretical concept of Christopher Hight, described in his book "Architectural Principles in the age of Cybernetics", 2008 [1] — is one of the theoretical breakthroughs of the early $21 \mathrm{st}$ century. The book excites with the very formulation of the problem, which sounds as a call to re-examine the underlying foundations of architecture. The purpose of the work is to secure the autonomy of the subject of architectural theory in the conditions of the onslaught of technologies in the sphere of creativity, on the one hand, and in the conditions of virtualization of the environment itself, on the other.

In the introduction, the author writes: "My primary site of examination is the sudden, and heretofore unexplained, reappearance of the human figure in mid-twentieth-century architecture and its relationship to recent interest in the body in reference to issues of post-humanism, digital technology, globalization and science"[2].

His research is based on the history of theoretical concepts of anthropomorphism, traditionally understood as the correlation of human form and human behavior with the 
divine and natural principles. Anthropomorphism is a worldview concept expressed both by the means of language, fine arts, and to a certain extent by the means of architecture. Christopher Hight explores the peculiar diffusion of proportional relations characteristic of modern architecture. He focuses on the discourse on proportions, while linking it to the current acute problems of technologization and posthumanism, penetrating into architecture. At the same time, he opens up some opportunities that are available only through new technologies.

Hight explores how the problems of the human body and the problems of human existence are taken into account in the most central part of the architectural discourse of recent decades. This is especially true in the context of recent attempts to simply reformulate the attitude of architecture to humanism, to modernity, to new technology. Hight questions a number of concepts and categories of architectural history, and at the same time a number of the concepts of contemporary debate, placing both series in a broader cultural and technological context. By doing so he makes the most complex ideas more accessible to understanding.

Hight explains his close attention to the category of body in architecture for two reasons. The first reason is the threat of general technological changes to the world. The second is his own desire to find the reserve of confrontation between the excessive technologization of the architectural project and the excessive technologization of a person and his environment.

Aqcuaintance with the book allowed to identify three of its main themes, which the author presents as eternal, but historically manifested differently in architectural thinking. The first is related to a phenomenological origin in architecture. The second is the comparison of the historical and modern methods of working with special models of an architectural space - the diagrams. The third is related to the comprehension of the architectural structure's proportions as the means of communication of architecture with the proportions of the human body or deliberate rejection of this principle. Hight explains that close attention to the category of the human body in the architecture of the 20th century arose in the work under the threat of technological changes. And, of course, there was a desire to find the reserve of confrontation: the excessive technologization of the architectural project, the man himself, and his environment.

\section{B. The Appeal to Phenomenology: Joseph Rykwert and Alberto Pérez-Gómez}

So, in the initial second chapter "Phenomenological roots of architecture" Hight paid special attention to a kind of a phenomenological explosion, directed against the excess of technology, which became noticeable at the end of the forties of the 20th century. The pathos of modern phenomenology is revealed on the theses of modern phenomenologists. One of them is a British-American historian and theorist of architecture Joseph Rykwert, who claims that the city is not the collection of well-planned residential units, but something more complicated and requiring a special approach. The Central argument of Joseph Rykwert in his study of the city is the phenomenon of the temptation of a "place" - that part of urban space where the city meets the request of the resident. Rykwert argues that the city must be a physical structure, consistent with the communities. In his book, he travels through historical and modern cities to trace their roots in ancient times and to outline current attempts and future opportunities to improve the metropolis of the 21 st century, created not for the benefit of corporations, but for the sake of residents [3].

Particular attention in the book is paid to the ideas of Rykwert's student Alberto Pérez-Gómez, the professor of the history of architecture at McGill University in Montreal, Canada. Pérez-Gómez believes that architectural purpose is metaphorical. But this metaphor may enter the phase of crisis if architecture begins to be described as the sign of problems of other disciplines, for example, technological ones. According to Pérez-Gómez, today it becomes clear that a professional correlates outstanding works of modern architecture with the specifically new architectural model of the human body, and not with the one that was the basis of classical architecture, based on an objective and unitary body [4].

Pérez-Gómez requires the architecture that can strengthen human values and capabilities, the architecture that is linked to its location and its inhabitants. He writes: "Clearly today, in a world of complex technological systems, we control, individually, very little; yet our actions ...have a phenomenal importance...This is why I would argue formalistic strategies in architecture, regardless of the legitimizing frame of reference (in Marxist theory, linguistics, physics, or evolutionary biology) may be dangerously irresponsible" [5].

However, Hight also comes to the need for an analytical approach to such ambitious phenomenology. Hight's analysis of the phenomenological paradigm leads him to the idea that "what they [philosophers] accomplish is not really a critique of technology and rationalization. Instead, they naturalize the modernist myth of autonomous technology and ever increasing instrumentalism and rationalism [...] we must question not only the grounds upon which they define modernity as a break with the Western tradition of the body, but also the usefulness of this tradition itself and its historical armature" [6].

Thus Hight largely agree with phenomenologists, but stresses that history does not go backwards. The polemic is likely to continue. This becomes quite possible after the release in 2016 of a new book by Perez-Gomez "Attunement: Architectural meaning after the crisis of modern science".

\section{The Diagrams - Classical, Modernist and Algorithmized, Rudolf Wittkower and Colin Rowe}

Rudolf Wittkower and Colin Rowe become the main reference figures of architectural philosophy in Hight's consideration of the second theme - which mapped historical and contemporary methods of working with such models of architectural space as diagrams. 
In 1949 the German-American historian Rudolf Wittkower, published a work that in the eyes of the architects became his masterpiece: "Architectural Principles in the Age of Humanism" [7]. The book became attractive for architects, but not so much due to the author's analysis of the proportions of the Renaissance villas, as through the use of diagrams and schemes as the method of architectural objects analysis in general.

Michael Leighton Beaman, Director of Beta-Field school at Harvard graduate school of design, in a note "Polemic continuity", dedicated to the book of Hight, notes: "Ultimately, Wittkower rendered architecture's intellectual content a product of an analytical system that utilized the diagram. It was not long before this concept of analysis in architecture evolved into a method for producing architecture" [8].

The idea of the diagram as a generative model for architectural design was originally used in studies of a Wittkower's student - Colin Rowe. In his essay "the Mathematics of the Ideal Villa", Colin Rowe constructed an assumption about the conceptual connection of a proportional order in Renaissance architecture and in Modernist architecture. On this basis, Rowe compares charts - Corbusian Villa Stein in Garches and the Palladian Villa Malcontenta. Rowe argues that there is the special principle of perception developed and embodied there - namely transcendent (outside of sensory experience) reading of the effects of technology and effects of the architecture [9]

Hight, along with his heroes, says that the diagram as the transcendental apparatus for designing a special "architectural form of knowledge" defines "continuity of history" of architectural thinking no matter what! It can be said that by doing so, Hight asserts the idea of the polemic continuity of architectural theory as a theme, as a metaphor, and as a model for his research.

However, Christopher Hight takes with care and sometimes criticizes modern diagrams born in the age of digital design. According to Hight, the use of modern diagrams in digital design does not always lead to success. For example, the project of the group UN STUDIO (Ben van Berkel and Carolyn Bos), created with the support of the "clover leaf" diagram has led to a creation of a plastically solid Museum Mercedes Benz design, allowing to contemplate the atrium space of the Museum.

Excessive use of complex diagrams can create an inhumane space, as it happened with the same company in the project of the Villa Mobius House, where the «Mobius tape» topological object is taken for the basis of the construction. Hight notes that the Villa moves away from the humane Palladian idea of architecture, that is, from the formation of a static and unified body in space, but also away from the modernist idea of a fragmented whole. It is obvious that the Central node in the Villa Mobius House is not a humane uplifting Center beneath the dome, but rather a discouraging road fork. Substitution of spatial symbols can destroy the integrity of the person, his perception of security in the house, destroy a kind of centrism as a guarantee of peace.

\section{The Third Theme of the Hight's Book-Corbusier's Modulor}

Hight is sure that his main position of the study was born out of his interest in a very unexpected, and previously inexplicable, but repetitive appearance of the human figure in architecture from about the middle of the twentieth century, from interest in this phenomenon as a fact, as well as from interest in the most recent movement of architectural analysts-in the field of bodily metaphors and other references All this became apparent especially clearly in the background of the debate on the values of post-humanism, digital technology, globalization and new science.

The chapters on the Corbusier's Modulor, or the work of Siegfried Giedion "Mechanization Takes Command" greatly amplify and highlight the gaps in modern architectural knowledge about the human body and about the mutation of this knowledge. There are three references to Corbusier's Modulor in the book. Modulor considered especially carefully in the chapters 4 and 9 . Hight consistently unfolds the history of the manifestation of the classical (Vitruvian) and modernist (corbusian) model in a modern architectural project. Unfolding the history of the classical model in the modern architectural project of the mid-20th century, Hight conducts a clear analysis of this phenomenon on an incredibly compressed area of his research.

\section{E. The Central Thesis of Christopher Hight - Reliance on the Philosophy of a "Symbolic Form"}

It is known, that the formats of thinking can be very different. Reading the book of Hight, we are able to follow the type of rational thinking resulting in a clearly reasoned concept, and symbolism revealing itself in artistic thinking. So what is winning today-stereotypical technologism or symbolism, hidden in the architect's style as an artist?

It seems that Hight approaches his central thesis in Chapter 7, which is called "the retaliation of symbolism". In Chapter 7, the author draws on the ideas of Marburg philosopher Ernst Cassirer, according to which art develops from mythical thought. The most important thing in the architectural creation of a symbolic form is then a structurally clear connection between universal meanings of the world and its external features, which it is represented by. Cassirer explained that "Under a "symbolic form" should be understood each energy of spirit [Geist] through which a spiritual [geistig] content or meaning is connected with a concrete sensory sign and is internally adapted to this sign" [10].

Reflecting on art, Cassirer argued: "the Unity of space that we build in aesthetic contemplation and creativity - in painting, plastic, architecture - lies in a completely different plane than the unity of space, represented in the postulates and axioms of geometry. In one case, we are dealing with the modality of the logical-geometric concept, in the other modality of artistic spatial imagination comes into force: in one case, the space is thought of as a set of interdependent definitions, a system of "principles" and "consequences", in the other - it is the original integrity, understood in the 
dynamic mutual transition of individual moments as a visual and intuitive-grasped unity" [11] .

It seems that Hight formulates his Central thesis on the model of the symbolist doctrine, which is based on the doctrine of Ernst Cassirer: the architectural idea should be wrapped in a sensual form, while maintaining a deep symbolic meaning. He is sure that there is an elusive stability of a special, though certainly historically variable, but still constant and consistent manifestation of the humanistic foundation of architecture. Thus, Hight gives hope for the indestructibility of architectural thinking.

Having calmed the reader in Chapter 7, the author, however, brings him in the last two chapters 8 and 9 to a very specific idea - to the idea of the inevitability of the emergence in the consciousness of an architect of a phenomenon called by the author an "intermediate body".

The idea of an intermediate body is proposed by Hight in three formats:

- in the format of a new definition, justified statistically;

- in the format of the imaginary stretching of the human body's natural boundaries in terms of its technological integration;

- in the format of the so-called "self-developing body", which is understood today as a precursor of a cybernetic body .

Hight argues that this kind of "techno-social hybrid" has already quietly emerged somewhere in the middle of the 20th century. The author proceeds from the acute probability of considering the model of a cybernetic - certainly not Vitruvian - man as the subject of future research of architecture.

In General, Hight's research is perceived as a kind of a program for the architect of the nearest future, adapted to the most unexpected disciplinary transformations. Hight encourages to mute the customary norm today in the critical discourse of architectural theory and go on to discuss formal, technical and theoretical problems of the actual profession.

\section{NeIL SPILlER AND THE PROBLEM OF THE EXTENSION OF REALITY}

\section{A. The Interest of a Modern Theorist to the Cybernetic Line in Architecture}

The second figure on the artistic and theoretical scene of architecture, certainly worthy of attention is Neil Spiller. Spiller is an architectural theorist, professor of architecture and digital theory at the London Bartlett School of Architecture since the 1990s, and has moved to Greenwich University as Dean of the school of architecture since 2014. It seems that Spiller is primarily a self-reflecting artist, as well as a researcher, constantly and actively "stretching the field" of architectural knowledge.

Approximately from the 1970s of Neil Spiller is interested in germination of cybernetic lines in architecture. In particular, the experience of London architect Cedric Price.
What attracted him to the concept of Price? The offering of a new type of architecture -the architecture of engagement and participation. Price himself described his Palace of Laughter as a "giant neo - futuristic machine" closely associated with the impending revolution - the revolution of programming.

\section{B. The Movement from Surrealism to Hyperreality}

The second important line of Spiller's reflection is surrealism. According to his confession, in the concept of surrealism he sees an effective way to attract the attention of the architect for the newest little-tested techniques, and strengthen the professional commitment to understanding the digital world. A new interpretation of the world - that's what is necessary for the designer, says Spiller. However, his so called "surreal experiences" - is rather a desire to work with a some kind of superreality. Already in the 1990s and later he actually works with this special substance - with the superreality. He is looking for an access into the superreality, supported by modern digital technology. The architect as an artist must capture and bring out this new, ultra-realism, this allusion, this mystique. And so to say tame her. His theoretical outcomes Spiller usually accompanies with drawings, in certanly not a realistic manner and in computer graphics.

\section{Digital Studies of the Hyperreality}

Since 2014 Spiller has been the head of the school at Greenwich University. He lectures on the background of a giant screen, where his computer pictures symbolically reproduce the concept of a movement to hyperreal.

In a short essay "Reflexive Urbanism in the forest of Signs" Spiller notes: "People have described my drawings as a kind of myth-making, and certainly my work over the last ten years has become very mythic. So I try to link to the Surrealist body of work, which I think was brave for its time, and use it to question some of the assumptions we (architects) have about our role in the contemporary world. Soon we'll be able to start to make spaces that aren't dictated by the tyranny of the planner or the aesthetic tyranny of the architect- what happens then?" [12].

\section{From the Studies of Superreality to Cyberspace and the Algorithmicity}

Spiller states: "Our intelligence is made out of virtual and real things, and the synthesis of the virtual and the real is where my explorations lie. Certainly, the idea of living in a pod with my bodily functions wired up to the sink is not a good thing. For me, architecture is embodied in a series of reflexive objects or narratives. I often say that architecture can exist from the microcosmic and the nanoscopic to the cosmographic. I'm interested in the blurred boundary between the virtual and actual as a space to speculate" [13].

What is algorithmicity? This is the way of learning algorithmic programming. The indecision of the architectural workshop in the development of the possibilities of expanding the virtual world seems to be drag to Spiller. He writes: "I am interested in what I call architecture of the second aesthetic, which is essentially algorithmic. I think 
there is a place for algorithmic architecture, but to explore it properly we might have to leave the computer behind and evoke the biotechnical" [14].

In his article of 2009, Spiller confesses "My research is centred upon how architecture is invigorated by cyberspace, the blurred boundary between the virtual and the actual, and how the different parameters of these spaces can be used to inform one another. My early experience in practice was that buildings are limited by the inert materials used to construct them and by the unimaginative ideas of what a building should look like and be. My research draws upon a variety of different disciplines to inform one - architecture. The areas of research are multidisciplinary and include the changing status of the architectural drawing, smart materials, computer-aided architectural drawing, computer-aided manufacture, emergent systems, responsive environments, the architectural design of cyberspace, interactivity, cybernetics and evolving systems and algorithmic design" [15].

He would like to increase the emotional impact of the project, with the help of programming. "To create responsive, non-prescriptive designs for architectural intervention was the starting point that led to an interest in the logic of algorithms and open-ended systems. These problem-solving diagrams used by computer programmers are very useful as a way of describing fluctuating conditions in responsive environments"'" [16].

Spiller is interested in contacts with avant-garde art schools created by artists such as Marian Coletti and Roy Escott and particularly in interactive installations, developed in a number of architectural schools in Britain, Canada, Australia, etc.

Spiller equates an art experiment built on interactive algorithms with an artistic research. In this position Spiller is close to the beliefs of Roy Escott, Professor of so-called "techno-ethics" and art at the faculty of technology at the University of Plymouth. Escott himself states: "An artistic research must produce its own rules; the artist as a researcher forms knowledge in new ways, creates a new language, new coordinate systems and reference points. Provokes new systems and even new behavior" [17].

While Spiller echoes: "We are at another of the important perturbations in technology and epistemology that seems to affect us so often these days. Cell biology is the new cyberspace and nanotechnology. Once we fully understand the exact nature of how our world makes us and, indeed how it sometimes kills us, we will be able to make true architectures of ecological connectability. This is our profession's future. Small steps have been made, but much more remains to be done. Once we fully understand the exact nature of how our world makes us and, indeed how it sometimes kills us, we will be able to make true architectures of ecological connectability. This is our profession's future. Small steps have been made, but much more remains to be done" [18].

\section{CONCLUSION}

So, if Christopher Hight is trying to gain the support of the ingerent specifics of architectural design, addressing at the same time to ancient and to the methods of diagrams and recalling the eternal spirit of human presence, with its bodily "tuning fork" in relation to space, weighing new possibilities, the experiments of Spiller consciously and aggressively move to qualitative changes in the very consciousness of the architect. It is important for him to understand that "dry digitalization is dead in itself". But it is necessary to have the movement of the soul of the architect as an artist, to born a work that reflects the same elusive pairing of the man with the energy of his era.

Spiller asserts the need to transform the consciousness of the architect. It is clear that the stability of the core of the profession is questioned. How humane is this position? It seems that it contains the very humanity that gives strength to overcome the unrecognized phenomenon that broke into life. In other words, the energy of knowledge of the changing world is supported here.

What unites these two authors? Both authors call for the expansion of consciousness. What shows their difference in approach to solving the problem? Christopher Hight is a highly intellectual theorist of architecture while Neil Spiller is no stranger to theorizing, but his thesis is dominated by the artist's passion. Because of that, what acts in the interpretation of Christopher Hight in the category of a disaster that must strained, in the interpretation Neil Spiller falls into the category of the resource.

It is obvious, that perhaps the main subject of discussion today is the consciousness of the architect, his readiness to create a living environment in the conditions of a cybernetic expansion of the world, the actual method of expanding reality in the consciousness of the artist-architect is his willingness to take a humanistic position.

\section{REFERENCES}

[1] Hight, Christopher. Architectural Principles in the Age of Cybernetics. - New York: Routledge, 2008.

[2] Hight, Christopher. Architectural Principles in the Age of Cybernetics. -- New York: Routledge, 2008. P.6.

[3] Rykwert, Joseph The Dancing Column: On Order in Architecture, MIT Press, Cambridge Massachusetts and London, England, 1996, 598 pages; Rykwert, Joseph. The seduction of place: the city in the twenty-first century. New York: Pantheon Books, c 2000. Physical description. xii, 283 p., [16] p. of plates : ill.

[4] Rykwert, Joseph The Dancing Column: On Order in Architecture, MIT Press, Cambridge Massachusetts and London, England, 1996, 598 pages; Rykwert, Joseph. The seduction of place: the city in the twenty-first century. New York: Pantheon Books, c 2000. Physical description. xii, 283 p., [16] p. of plates : ill.

[5] Perez-Gomez, Alberto. Architecture and the Crisis of Modern Science. Cambridge, MA: MIT Press. 1983. P.311.

[6] Hight, Christopher. Architectural Principles in the Age of Cybernetics. -- New York: Routledge, 2008. Pp.30,31.

[7] Wittkower, Rudolf. Architectural Principles in the Age of Humanism. 2nd edition. London: Tiranti, 1952.

[8] Beaman, Michael Leighton. Contested continuities. Architectural Principles in the Age of Cybernetics by Christopher Hight // 
"readings" fall. 2009 cite [http://citemag.org/wpcontent/uploads/2009/11/Cite_80_Readings_Beaman.pdf].

[9] Colin Rowe. The Mathematics of the Ideal Villa and Other Essays. Cambridge. MA: MIT press. (1976).

[10] Bayer TI (2001) Cassirer's Metaphysics of Symbolic Forms: A Philosophical Commentary; with an Introduction by Donald Phillip Verene. New Haven, CT, and London: Yale University Press.

[11] Cassirer E. Philosophy of Symbolic Forms. New Haven \& London: Yale University Press, 1980. p. - C.31

[12] Spiller Neil. Reflexive Urbanism in the Forest of Signs [http://www.gre.ac.uk/schools/arc/rss-assets/news/futurecities/programme-and-abstracts/neil-spiller].

[13] Spiller Neil. Reflexive Urbanism in the Forest of Signs [Electronic resource] http://www.gre.ac.uk/schools/arc/rss-assets/news/futurecities/programme-and-abstracts/neil-spiller.

[14] Spiller Neil. Reflexive Urbanism in the Forest of Signs [Electronic resource] http://www.gre.ac.uk/schools/arc/rss-assets/news/futurecities/programme-and-abstracts/neil-spiller.

[15] Spiller, Neil. Plectic Architecture: Towards a Theory of the Postdigital in Architecture.// Technoetic Arts: A Journal of Speculative Research, 2009. № 7 (2). pp. 95-104.

[16] Spiller, Neil. Plectic Architecture: Towards a Theory of the Postdigital in Architecture.// Technoetic Arts: A Journal of Speculative Research, 2009. № 7 (2). pp. 95-104.

[17] Interview with Roy [http://iskusstvo.msk.ru/2009/4_5/18ascott.htm].

Ascott.

18] Spiller, Neil. Plectic Architecture: Towards a Theory of the Postdigital in Architecture.// Technoetic Arts: A Journal of Speculative Research, 2009. № 7 (2). pp. 95-104. 